\title{
複列潜堤の波浪制御効果と非線形干渉特性 WAVE CONTROL BY TWO TRAINS OF SUBMERGED BREAKWATER
}

\author{
山城 賢 1 -吉田明徳 2 - 入江 功 3 \\ Masaru YAMASHIRO, Akinori YOSHIDA and Isao IRIE \\ 1正会員 工博 (侏)エコー 環境水理部（广110-0011 東京都台東区北上野2-6-4） \\ 2 正会員 工博 九州大学大学院助教授 工学研究科 (T812-8581 福岡県福岡市東区箱崎 6-10-1) \\ 3正会員 工博 九州大学大学院教授 工学研究科（干812-8581 福岡県福岡市東区箱崎6-10-1）
}

\begin{abstract}
The purpose of this study is to numerically investigate the wave control effect of two trains of submerged breakwaters located a certain distance apart and the non-linear interaction between the breakwaters and random waves. The numerical method is the so-called boundary integral method in which Green's Identity Formula is used for the expression of the velocity potential of wave motion. The reflection coefficients are calculated for several cases of the two trains of submerged breakwaters, and for a single submerged breakwater which has the same width as the width added up the two train of the submerged breakwaters as well. The power spectra of the water surface oscillations behind the submerged breakwaters are further calculated for each case. By comparing the reflection coefficients and the power spectra of the water surface oscillations, it is found that two trains of submerged breakwaters is more effective on wave control than a single submerged breakwater.
\end{abstract}

Key Words : Two trains of submerged breakwater, reflection coefficient, non-linear interaction random waves

\section{1.まえがき}

複列潜堤は, 潜堤幅が比較的小さな潜堤を岸沖方 向に複数列配置することによって, 単一の, 広天端 幅の潜堤と同等あるいはより好ましい波浪制御効果 を得ようとするものであり, 特に, 岸からかなり離 れた大水深域に潜堤を設置しようとする場合には, 単一の潜堤では大断面となるため, 複列潜堤は施工 上および経済的に非常に有利といえる. 複列潜堤を 対象とした研究としては, 吉田ら ${ }^{1)}$, 喜岡 ${ }^{2)}$, Bailard $ら^{3)}$ ，喜岡ら 4 , 5)等によるものがあり，その波浪制御 効果については理論的および実験的に検討され, 潜 堤の設置間隔を入射波の半波長に取った場合, 反射 による防波効果が著しく高まるという知見が得られ ている. しかし, 既往の研究では入射波はすべて規 則波として取り扱われており, 広い周波数にわたっ てパワーを有する不規則波が入射する場合の研究例 は無い。 また, 波と複列潜堤の非線形干渉特性を検 討した例としては, 喜岡ら5)のBoussinesq方程式によ るものがあるのみである. 潜堤を設置する海域を大 水深域と想定した場合, 入射波としては規則波より 不規則波を考える方が妥当であると思われる.また， 潜堤背後海域では波と潜堤との非線形干涉の結果励 起した高次の周波数成分により, 水面波形および流 速波形は非対称性を有するようになる. 波形の非対

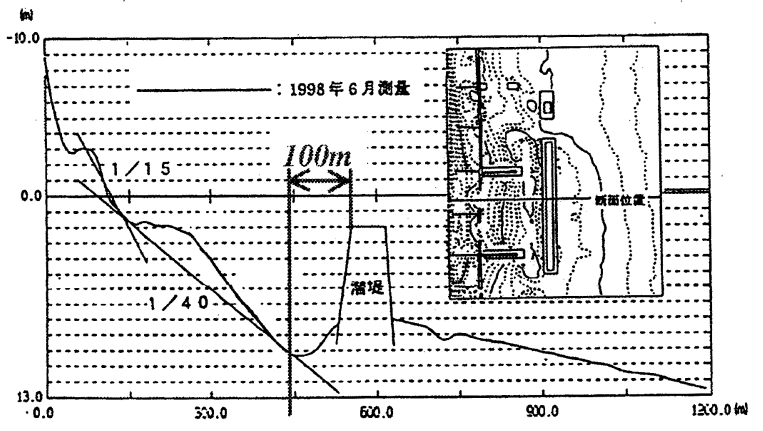

図-1 断面地形 (新潟西海岸)

称性は漂砂に強く影響し海底洗掘の原因となる．例 として図-1に汀線からおよそ $400 \mathrm{~m}$ の沖合に大規模な 潜堤を設置している新潟西海岸の断面地形図を示す. 新潟西海岸では潜堤から約 $100 \mathrm{~m}$ 岸側の位置でおよ そ $4 \mathrm{~m}$ の海底洗掘が生じており，この洗掘の原因は 底面流速波形の非対称性と考えられる6). したがっ て, 潜堤背後の海底地形変化を把握するためにも, 波形の非対称性の原因となる波と潜堤との非線形干 渉効果について検討することが重要と考えられる.

以上の観点から, 本研究は, 複列潜堤を対象に理 論解析法による数值実験を行い, 不規則波と複列潜 堤（二列潜堤）との非線形干渉特性について検討し たものである. 


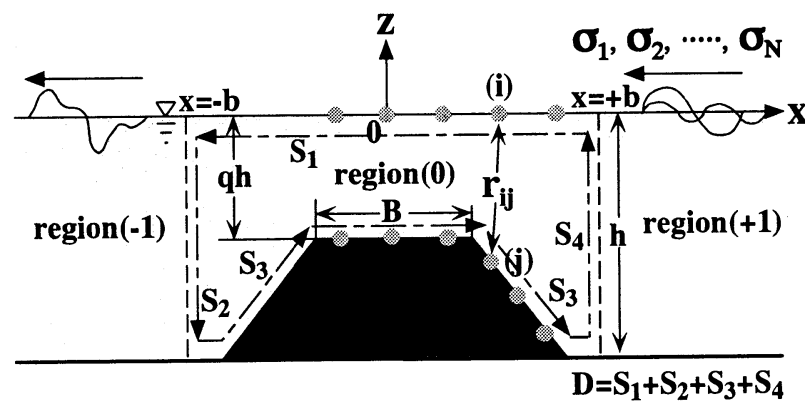

図-2 計算領域

\section{2. 数値実験}

\section{（1）理論解析法の概略}

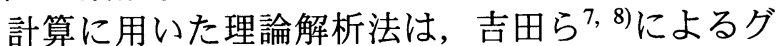
リーン公式と摂動展開法を併用する波と没水構造物 との非線形干渉解析法で，図-2に示すように，流体 域を反射波領域と通過波領域の開領域と，仮想境界 面によって囲まれる構造物近傍の閉領域に分割し， 開領域では 1 次と 2 次のオーダーについて, あらか じめ水面条件と水底条件を満足する速度ポテンシャ ルの解析解を求めておき，これらの解析解から得ら れる仮想境界面の境界条件と，水面境界条件，およ び構造物上の境界条件を満足するように，閉領域の ポテンシャルの表示に用いたグリーン公式（式(1)） を数值的に解くものである.

$\phi(X)=\frac{1}{\alpha} \int_{D}\left\{\phi\left(X_{b}\right) \frac{\partial}{\partial \nu} G(r) \quad G(r) \frac{\partial}{\partial \nu} \phi\left(X_{b}\right)\right\} d s$

ただし, $G(r)=\log r+\log r *$ で $r$ は領域内の任意点 $X=(x, z)$ と境界線 $D$ 上の点 $X_{b}=\left(x_{b}, z_{b}\right)$ との距離 で, $r^{*}$ は $X$ と $X_{b}^{*}$ (水深一定の海底面に対する $X_{b}$ の鏡像点）間の距離である. また， $\alpha$ は $X$ が境界 線上にある場合は $\alpha=\pi$ を取り，境界線を除いた領 域内の点である場合は $\alpha=2 \pi$ を取る定数で, 領域 (0)に対する外向き法線を $\boldsymbol{v}$ とし, 積分は境界（水 面，仮想境界面，構造物表面）に沿う半時計回りの 積分である. 各周波数成分についての数值解析の方 法は吉田ら ${ }^{7,8)}$ の場合とまったく同じである.

\section{（2）計算条件}

本研究では, 大断面の単一潜堤の1ケースと複列 潜堤（二列潜堤）の8ケースについて計算を行った. 計算の条件は, 潜堤は斜面勾配が $1: 1$ の台形型不透 過潜堤とし, 複列潜堤のケースでは, 図-3に示す天 端水深と天端幅および設置間隔を変化させて配置し た（表-1参照）。入射波はBretschnider-Mitsuyasu spectrumにおいてh/ $\left(\mathrm{gT}_{1 / 3}{ }^{2}\right)=0.019, \mathrm{H}_{1 / 3} / \mathrm{L}_{1 / 3}=0.013 （ \mathrm{~h}$, $\mathrm{g}, \mathrm{L}_{1 / 3}$ はそれぞれ水深, 重力加速度, 有義波の波 長）とした。

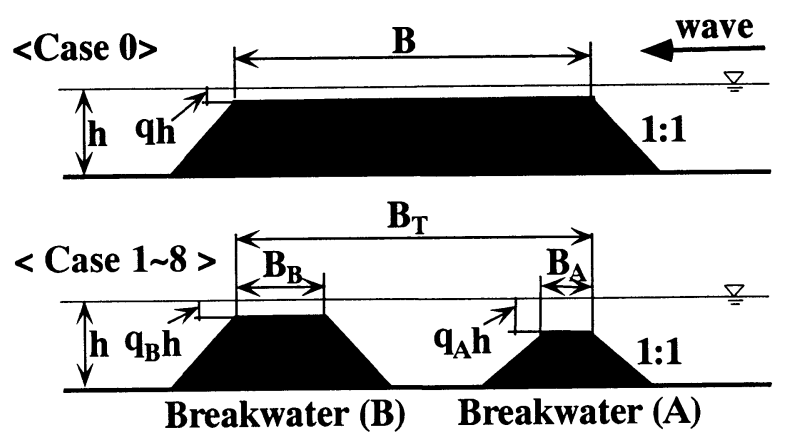

図-3 単一潜堤と複列潜堤

表-1 潜堤の諸元

\begin{tabular}{|c|c|c|c|c|c|}
\hline & \multicolumn{5}{|c|}{ Single Submerged Breakwater } \\
\hline & \multicolumn{2}{|c|}{$\mathbf{q}$} & \multicolumn{2}{|c|}{$\mathbf{B} / \mathbf{h}$} & \\
\hline \multirow[t]{4}{*}{\begin{tabular}{|l|} 
Case 0 \\
\end{tabular}} & \multicolumn{2}{|c|}{0.2} & \multicolumn{2}{|c|}{4.0} & \\
\hline & \multicolumn{5}{|c|}{ Two Trains of Submerged Breakwater } \\
\hline & \multicolumn{2}{|c|}{ Breakwater (A) } & \multicolumn{2}{|c|}{ Breakwater (B) } & \multirow{2}{*}{$\mathbf{B}_{\mathrm{T}} / \mathbf{h}$} \\
\hline & $\mathbf{q}_{\mathbf{A}}$ & $\mathbf{B}_{\mathbf{A}} / \mathbf{h}$ & $\mathbf{q}_{\mathbf{B}}$ & $\mathbf{B}_{\mathbf{B}} / \mathbf{h}$ & \\
\hline Case 1 & 0.2 & 1.0 & 0.2 & 1.0 & 4.0 \\
\hline Case 2 & 0.3 & 1.0 & 0.3 & 1.0 & 4.0 \\
\hline Case 3 & 0.2 & 1.0 & 0.2 & 1.0 & 6.0 \\
\hline Case 4 & 0.2 & 0.5 & 0.2 & 0.5 & 4.0 \\
\hline Case 5 & 0.3 & 1.0 & 0.2 & 1.0 & 4.0 \\
\hline Case 6 & 0.3 & 0.5 & 0.2 & 1.0 & 4.0 \\
\hline $\begin{array}{l}\text { Case } 7 \\
\end{array}$ & 0.2 & 1.0 & 0.3 & 0.5 & 4.0 \\
\hline Case 8 & 0.3 & 1.0 & 0.2 & 0.5 & 4.0 \\
\hline
\end{tabular}

\section{（3）評価方法}

各ケースについて，波浪制御効果として反射率を, 非線形干渉特性として通過波領域の水面振動のパ ワースペクトルを算定し，単一潜堤のケースを含め 各ケースにおける反射率とパワースペクトルの比較 により複列潜堤における波浪制御効果と非線形干渉 特性を検討した。

\section{3. 結果と考察}

\section{（1）波浪制御効果}

波浪制御効果を表わす指標として反射率を考える. 反射率は線形理論（1次のオーダ一）により求めら れ，非線形成分の影響は含まない.

\section{a）単一潜堤と複列潜堤との比較}

図-4に単一潜堤のCase 0 と複列潜堤のCase 1 による 反射率の比較を示す。図の横軸は入射波の無次元波 数khである. 図より，大断面の単一潜堤に対し，複 列潜堤では反射率のピークが現われる間隔がkhに対 し広くなっており，また， $\mathrm{kh}<0.35$ の長波長の波を 除くと, 全体的に単一潜堤の場合に比べ反射率が高 い。これは，特に風波に対して，小規模の潜堤を複 


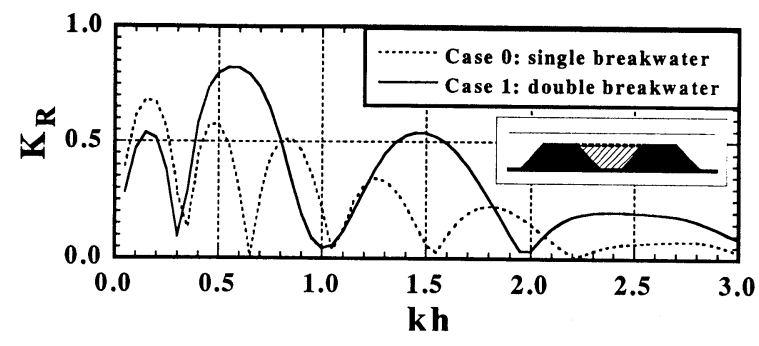

図-4 単一潜堤と複列潜堤による反射率の比較

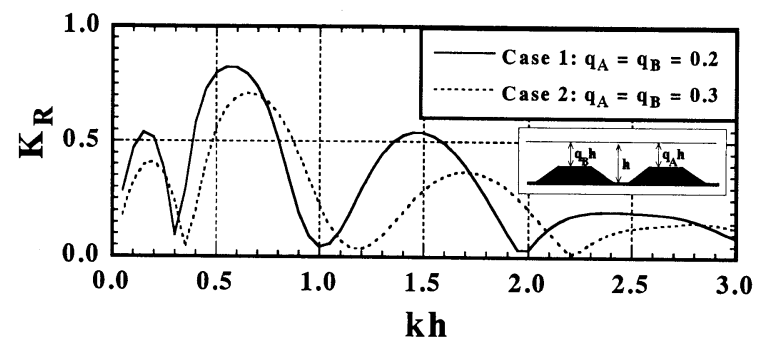

図-5 複列潜堤による反射率の比較 （天端水深の変化）

数設置することで，大断面の単一潜堤以上の波浪制 御効果を得ることが可能であることを示している. 以下に, 複列潜堤の設置条件の違いによる反射特性 について検討する.

b) 天端水深の変化

図-5は二つの潜堤の天端水深がともに $\mathrm{qh}=0.2 \mathrm{~h}$ の Case 1 とqh=0.3hのCase 2 の場合を比較したものであ る. 天端水深が浅いCase 1 の結果に比べ, 天端水深 が深いCase 2の結果は反射率のピークが現われる無 次元波数 $\mathrm{kh}$ が大きく，短周期側へ移動するとともに， ピークが現われる無次元波数の間隔が広くなる。ま た, 反射率のピーク值は天端水深が浅いCase 1 の場 合が高いが, 天端水深により入射波の無次元波数に 対する反射特性が変化するため, 入射波の波数に よっては天端水深を低くすることで反射率が高くな る場合もある.

\section{c）設置間隔の変化}

図-6に二つの潜堤の間隔（図-3に示す $\mathrm{B}_{\mathrm{T}}$ で表わ す）が $\mathrm{B}_{\mathrm{T}} / \mathrm{h}=4.0$ のCase 1 と $\mathrm{B}_{\mathrm{T}} / \mathrm{h}=6.0$ のCase 3 の結果を 示す．潜堤の設置間隔が広いCase 3の場合は, Case 1の結果に比べ, 反射率のピークが長周期側へ移動 し, $\mathrm{kh}=0.85$ 付近およびkh=1.1付近に小さなピークが 現われ，ピークが現われる間隔が狭くなっている. 喜岡ら ${ }^{4)}$ は矩形潜堤を複数列配置した場合について, 入射波の波数に対する反射率の特性を検討し，反射 率のピークは潜堤の設置間隔が大きいほど反射率の ピークを示す曲線は狭帯化するとともに, 長周期側 ヘシフトする傾向があると述べており, 図-6は喜岡 らの結果と同じ結果を示している.

\section{d）天端幅の変化}

図-7に二つの潜堤の天端幅がともに $\mathrm{B} / \mathrm{h}=1.0$ の Case 1 と $\mathrm{B} / \mathrm{h}=0.5$ のCase 4 の結果を示す. $\mathrm{B}_{\mathrm{T}} / \mathrm{h}$ はCase 1 , Case 4 ともに 4.0 である. 図より, 潜堤の天端幅が異 なると, 特に 3 番目のピーク以降で大きく反射特性

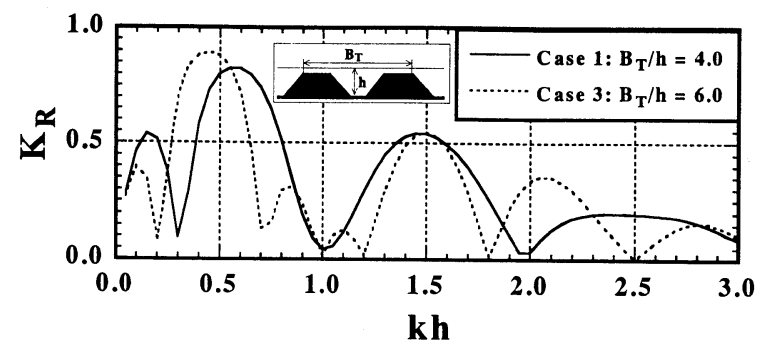

図-6 複列潜堤による反射率の比較 （設置間隔の変化）

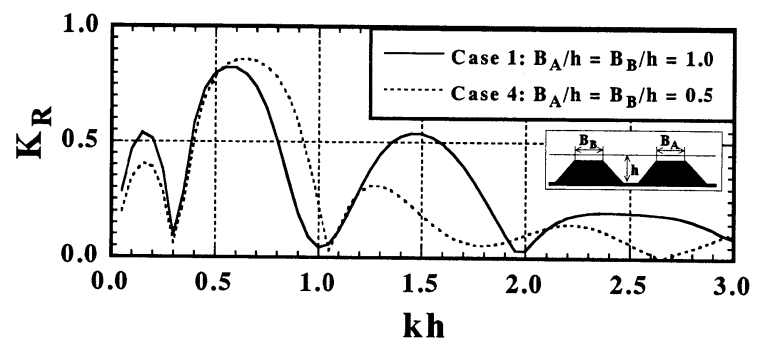

図-7 複列潜堤による反射率の比較 （天端幅の変化）

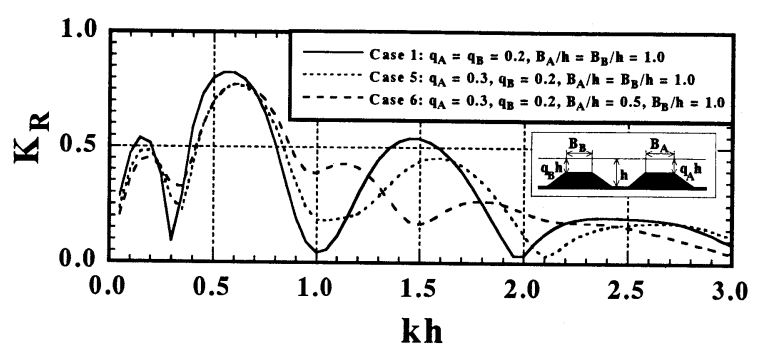

図-8 複列潜堤による反射率の比較 （天端水深と天端幅の変化）

が変化し, $\mathrm{kh}>1.2$ では潜堤の天端幅を狭くすること で反射率が減少している. しかし，2 番目のピーク 付近では, 逆に, 天端幅が狭いCase 4の場合が高い 反射率を示している.これは，潜堤の幅が狭くても， 入射波の周波数分布に対応して適切に潜堤を配置す ることで, 高い反射効果が期待できることを示して おり, 大断面の単一潜堤に比べ大きな利点といえる. e）天端水深と天端幅の変化

ここまで，同一の潜堤を複列配置した場合につい て, 潜堤の諸元である天端水深, 天端幅および潜堤 の設置間隔の変化にともなう反射特性の変化につい て検討した. 次ぎに, 断面が互いに異なる潜堤を配 置した場合の反射特性について検討する。図-8は Case 1，5，6の結果を示している. Case 1，5，6の 岸側の潜堤は全て同一の形状であるが, 沖側の潜堤 については, Case 1は岸側の潜堤と同一で, Case 5 は岸側の潜堤に比べ天端水深が深く, Case 6は岸側 の潜堤に比べ天端水深が深く, 且つ, 天端幅が狭い 場合で, Case 5, 6が断面形状が異なる潜堤を配置し た場合である. 図より, 同一の潜堤を配置したCase 1 と沖側に天端水深が深い潜堤を配置したCase 5 は無 次元波数に対する反射特性が若干異なるものの大き な変化はないといえる. Case 1, 5の結果に比べ, 沖 


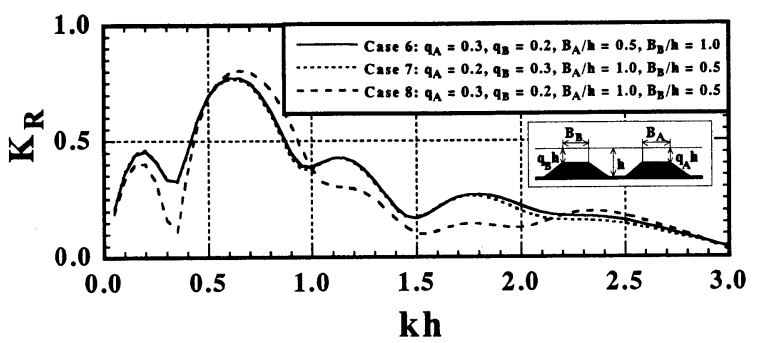

図-9 複列潜堤による反射率の比較 （天端水深と天端幅の変化）

側の潜堤の天端水深が深く天端幅が狭いCase 6の結 果は, 図に示す $0.0<\mathrm{kh}<3.0$ の範囲において, 反射率 が 0 となる無次元波数が存在せず，広い範囲の無次 元波数に対し有意の反射率を有している. Case 6は, Case 1，5に比べ，最も建設材料を削減できる場合で あり，大断面の単一潜堤に比べると，遥かにコスト 面および施工面で有利であると思われる．図-8に示 すように，断面の小さな潜堤を適切に配置すること で, 大断面の単一潜堤以上の反射効果を得ることが 可能であり，また，広い周波数帯にわたってパワー を有する不規則波を対象とする場合，複列潜堤は静 穏海域の確保という点で非常に有効であるといえる.

図-9に断面が異なる潜堤を配置したCase $6,7,8$ の場合についての解析例を示す. Case 6とCase 7は 岸側と沖側の潜堤を逆にした場合であり, Case 8は Case 7の条件で, 岸側と沖側の潜堤の高さを逆にし たものである. 図より, 潜堤を岸側と沖側で逆に配 置したCase 6とCase 7の結果がほぼ一致しており, 非常に興味深い. また, Case 8の結果もCase 7, 8に 比べ大差はなく．ここで行った解析の条件では, 断 面が異なる潜堤を配置することによる反射特性の変 化は小さい,

\section{（2）非線形干渉特性}

入射波各成分に与える位相によって 2 次のオー ダーの通過波スペクトルが幾分変動するが, 簡単の ため入射波各成分に与える位相は全てのケースにつ いて一定として計算した. また, 2 次のオーダーの 周波数成分波には, 位相速度の異なる拘束波成分と 自由波成分が共存するため, 水面変動のパワースペ クトルは, 空間的に幾分変動するが, これも簡単の ため水面変動のパワースペクトルは全て $\mathrm{x} / \mathrm{h}=-8.0$ の 位置において算定した。

\section{a) 単一潜堤と複列潜堤との比較}

図-10は単一潜堤のCase 0 と複列潜堤のCase 1 の比 較である. 単一潜堤と複列潜堤では水面変動のパ ワースペクトルの形状が明らかに異なっている. Case 0では, $\mathrm{f}=1.5 \mathrm{~Hz}$ 付近に 2 次のオーダーのピーク が現われているが, Case 1ではf $=1.5 \mathrm{~Hz}$ 付近にピーク が存在するものの, その值はCase 0の6割程度である. また, Case 0では, $\mathrm{f}>2.0 \mathrm{~Hz}$ の高周波数帯に有意なパ ワーは存在しないが, Case 1 では $\mathrm{f}=2.0 \mathrm{~Hz}$ 付近にピー クが存在し, 高周波数帯において大きく異なるスペ クトル形状を示している. 複列潜堤では, 第一の潜

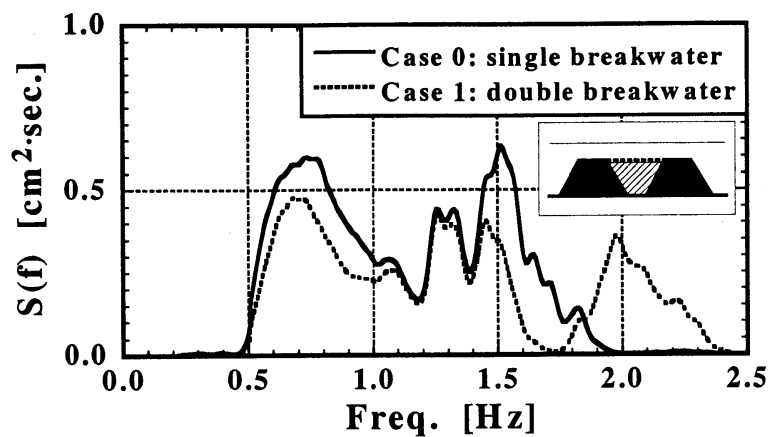

図-10 背後海域における水面変動のパワースペクトル （単一潜堤と複列潜堤）

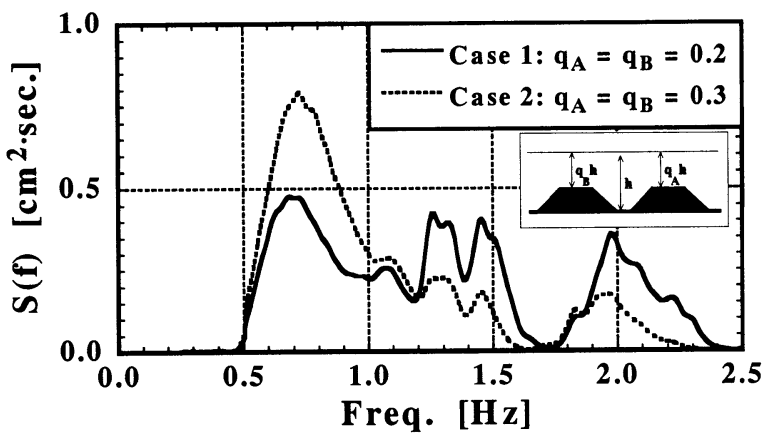

図-11 背後海域における水面変動のパワースペクトル （天端水深の変化）

堤を通過した非線形干渉効果を受けた波が，第二の 潜堤を通過する際に再び非線形干渉を生じ，このた め, 単一潜堤の場合と比べると高周波数成分波がよ り大きく励起されるものと思われる. 1 次のオー ダーである基本周波数成分が大部分を占める $0.5 \mathrm{~Hz}<\mathrm{f}<1.0 \mathrm{~Hz}$ では, Case 1 の場合がCase 0に比べ減 少しており，複列潜堤により反射率が高くなること が一因と思われる. 以下に, 複列潜堤の設置条件の 違いによるパワースペクトルの変化について検討す る.

\section{b）天端水深の変化}

図-11は二つの潜堤の天端水深がともに $\mathrm{qh}=0.2 \mathrm{~h}$ の Case 1 と $\mathrm{qh}=0.3 \mathrm{~h}$ のCase 2 の比較である. 天端水深の 違いにより, 非線形干渉効果が異なることがわかる. 天端水深が深いCase 2は天端水深が浅いCase 1に比 ベ, 1 次のオーダーが大部分を占める $0.5 \mathrm{~Hz}<\mathrm{f}<1.0 \mathrm{~Hz}$ の周波数帯において大きなパワーを 有しており, 反面, 2 次のオーダーが大部分を占め る $1.0 \mathrm{~Hz}<\mathrm{f}$ では小さい。これは潜堤上で砕波が生じ ない条件であれば，天端水深が浅くなるほど非線形 干渉効果が大きくなり，高次のオーダーの成分波が 活発に励起するという単一潜堤の場合に得られた結 果と同じである. また，2 次のオーダーの成分波が 励起する程度は天端水深により異なるが, 高周波数 帯において，ピークが現われる周波数はCase 1 と Case 2で一致しており, 天端水深が異なる場合でも, 2 次の成分波の周波数分布は定性的には同じである といえる. 


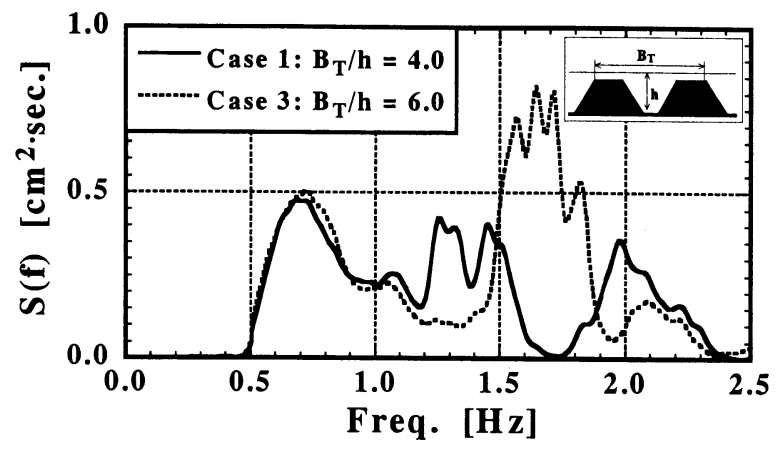

図-12 背後海域における水面変動のパワースペクトル （設置間隔の変化）

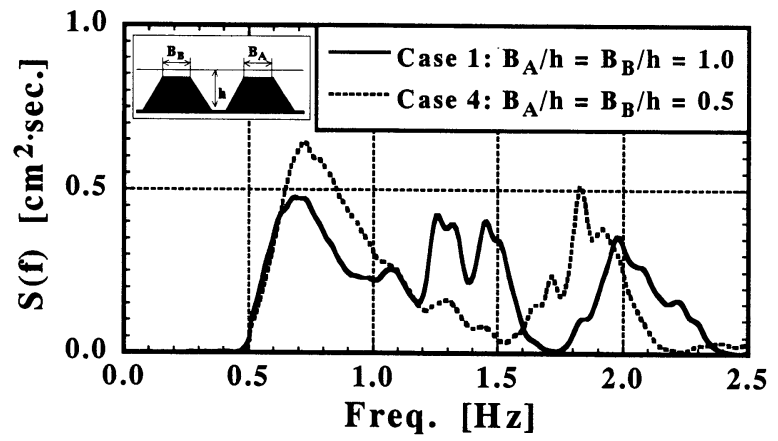

図-13 背後海域における水面変動のパワースペクトル （天端幅の変化）

\section{c）設置間隔の変化}

図-12に潜堤間隔が異なる， $\mathrm{B}_{\mathrm{T}} / \mathrm{h}=4.0$ Case 1 と $\mathrm{B}_{\mathrm{T}}$ $/ \mathrm{h}=6.0$ のCase 3 の結果を示す. Case 1 とCase 3 では $1.2 \mathrm{~Hz}<\mathrm{f}$ の 2 次のオーダーが大部分を占める高周波 数成分の分布が大きく異なり, 潜堤間隔が異なると 非線形干渉特性が大きく変化することがわかる．特 にCase 3 の $1.5 \mathrm{~Hz}<\mathrm{f}<1.8 \mathrm{~Hz}$ では，2 次のオーダーの成 分波のパワーが 1 次のオーダーを大きく凌駕してい る.しかし，1 次のオーダーの成分についてはほぼ 同じスペクトル形状を示しており，このことから， 潜堤の設置間隔によって 2 次のオーダーの成分を制 御することが可能であるといえる.

\section{d）天端幅の変化}

図-13に二つの潜堤の天端幅がともに $\mathrm{B} / \mathrm{h}=1.0$ の Case 1 と $\mathrm{B} / \mathrm{h}=0.5$ の Case 4 の絬果を示す. 潜堤の天端 幅が異なると, スペクトルの形状が全体的に大きく 変化している. 図-7のCase 1 とCase 4の反射率の結果 では, 1 次のオーダーの周波数帯 (およそ $0.5 \mathrm{~Hz}<\mathrm{f}<1.2 \mathrm{~Hz}$ )における反射率に大きな違いはみら れないが, 図-13の結果は, 2 次の成分が発達する 天端の幅が異なることで, 非線形干渉特性が変化し, 潜堤背後海域における水面変動のパワースペクトル が大きく変化することを示している.

\section{e）天端水深と天端幅の変化}

図-14はCase 1，5，6の結果を示している. Case 1, 5, 6の岸側の潜堤は全て同一の形状であるが，沖側 の潜堤は各ケースで異なる. 各ケースの潜堤の諸元 は図に示している. Case 1とCase 5を比較すると,

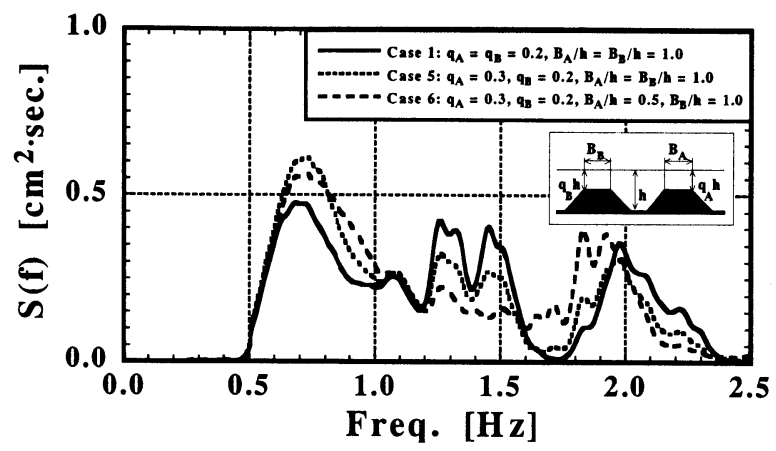

図-14 背後海域における水面変動のパワースペクトル （天端水深と天端幅の変化）

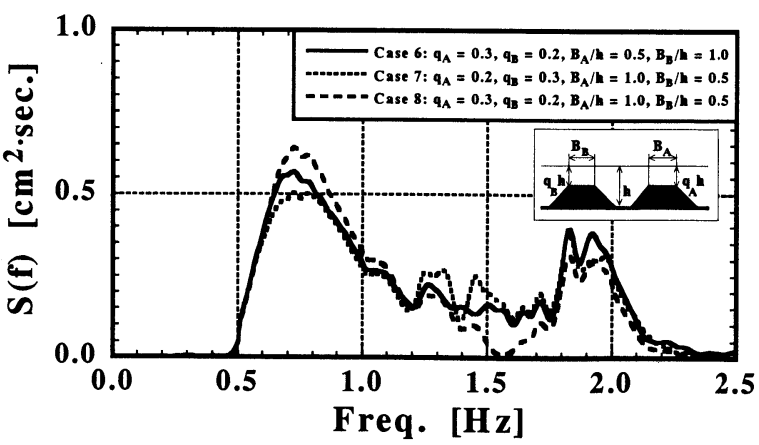

図-15 背後海域における水面変動のパワースペクトル （天端水深と天端幅の変化）

大きさの程度は異なるが, ピークが現われる周波数 はほぼ一致しており, 図-11における天端水深の比 較の結果と定性的な周波数特性は同じであるといえ る.この二つのケースは, 図-8にみられるように, 入射波の無次元波数に対する反射特性も非常に似て いる. Case 6になると, 沖側の潜堤の天端幅を狭く することで, 若干, 非線形干渉特性が変化しており, Case 6のスペクトルはCase 1のスペクトルと図-13に 示すCase 4のスペクトルの中間的な形状を示してい る.

図-15に断面が異なる潜堤を配置した場合につい ての解析例を示す. 図中の結果は, Case 6, 7, 8の 結果で, Case 6 とCase 7は岸側と沖側の潜堤を逆に した場合であり, Case 8はCase 7の条件で, 岸側と 沖側の潜堤の高さを逆にしたものである. 岸側と沖 側の潜堤を逆にしたCase 6とCase 7は, 図-10に示し た入射波の無次元波数に対する反射率では，ほぼ等 しい結果となっていた．潜堤背後における水面変動 のパワースペクトルも, Case 6とCase 7ではほぼ等 しく, Case 8も含めてスペクトル形状に大差はない.

\section{（3）背後海域における波のパワー}

ここまで, 潜堤の諸元および潜堤の設置間隔の変 化に対する水面変動のパワースペクトルについて定 性的な検討を行った．ついで，パワースペクトルを 積分して得られる波のパワーを各ケースについて比 較し, 定量的な検討を行う。図-16は, スペクトル 全体の積分值 $\mathrm{P}_{\mathrm{A}}$, ほぼ 1 次のオーダーの成分が占め 


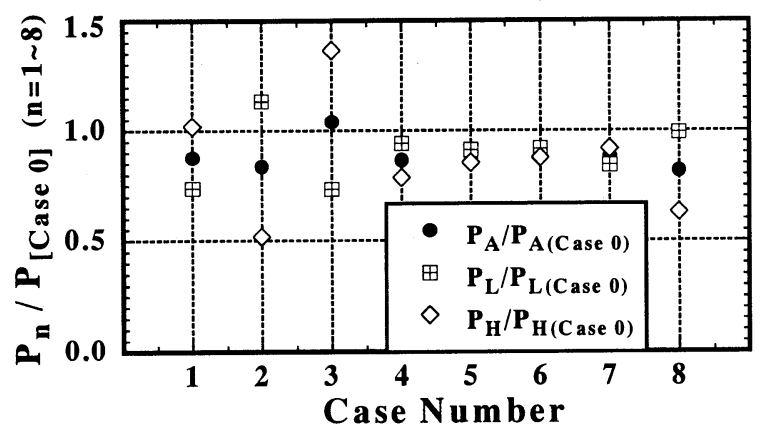

図-16 背後海域における水面波のパワーの比較

る低周波数帯 $\mathrm{f}<1.1 \mathrm{~Hz}$ の積分值 $\mathrm{P}_{\mathrm{L}}$ および 2 次のオー ダーの成分が大部分を占める高周波数帯 $1.1 \mathrm{~Hz}<\mathrm{f}$ の 積分値 $\mathrm{P}_{\mathrm{H}}$ ， 単一潜堤のCase 0の場合を基準とし, 他のケースとCase 0 との各パワーの比を示したもの である. スペクトル全体の積分値である $\mathrm{P}_{\mathrm{A}}$ をると, Case 3を除く全てのケースで, 1.0以下であり, 単一 潜堤の場合に比べ, 複列潜堤の方が潜堤背後域にお ける波のパワーをより大きく抑制することがわかる. 低周波数帯および高周波数帯のパワー $\mathrm{P}_{\mathrm{L}}, \mathrm{P}_{\mathrm{H}}$ をる と, 複列潜堤の配置の条件により, 潜堤背後海域に おける相対的なパワーの割合が変化することがわか る. 特にCase 3では, 単一潜堤の場合に比べ, 高周 波数帯のパワーが約 1.4 倍にまで達しており, 反面, 低周波数帯のパワーは単一潜堤の7割程度に減衰し ているものの, 全体的なパワーは単一潜堤に比べ増 加する結果となつている. Case 5，6，7は低周波数 帯のパワーおよび高周波数帯のパワーがともに単一 潜堤の8～9割程度となっている.

\section{4. あとがき}

複列潜堤による反射特性を検討した結果，単一潜 堤以上の反射効果を期待できるという知見を得た.

しかし, 非線形干渉によるスペクトル形状の変化に ついては, 複列潜堤では単一潜堤に比べ大きく変化 し，特に高周波数帯に通過波のパワーが拡大する傾 向があることがわかった。 また，複列潜堤の非線形 干渉特性は，特に潜堤の設置間隔や，個々の潜堤の 天端幅が大きく影響することが明らかになった．複 列に配置した潜堤間で，単一潜堤の場合にはみられ
ない渦や重複波が生じることが考えられ，加えて， 高波浪時には潜堤上で砕波が生じ，反射および通過 特性が変化する．数值実験では考慮していない渦や 砕波が波浪制御効果にどのように作用するかといっ た点については実験による検討が必要である.

波と複列潜堤との干渉には，潜堤の天端水深や天 端幅および設置間隔に加え，入射波の有義周期や有 義波高および入射波を構成する各周波数成分の位相 差などが大きく影響するため，ここで述べたケース のみの検討では十分ではないが，本研究の結果，少 なくとも, 複列潜堤が単一潜堤以上の波浪制御効果 を有する可能性は確認されたものと思われる.

謝辞

本論文の原稿作成に関しては，九州大学大学院海 洋システム工学専攻の修士学生越智宏充君の助力を 得た。記して謝意を表す。

\section{参考文献}

1) 吉田明徳, 木佐貫徹, 古賀諭志, 小島治幸: 複列鈶直 版潜堤による波の制御, 第35回海岸工学講演会論文集, pp. $537-541,1988$.

2) 喜岡渉: 複数列配置した潜堤による波の反射, 土木学 会論文集，第411号，pp. 263-266，1989.

3) Bailard, J. A., J. Devries, J. T. Kirby and R. T. Guza: Bragg reflection breakwater: a new shore protection method?, Proc. of the 22 th Int. Conf. on Coastal Eng., pp. 1702-1715, 1990.

4) 喜岡渉, 松野忠幸, 源川秀樹: 複数列配置した潜堤に よる波浪制御, 海岸工学講演会論文集, 第 36 巻, pp. 549-553, 1989 .

5）喜岡渉, 水谷幸平：傾斜海浜に配置した二列潜堤によ る波浪制御, 海岸工学講演会論文集, 第38巻, pp. 566570, 1991.

6）山城賢: 不規則波と構造物との非線形干渉解析法と潜 堤背後の波動場特性に関する研究, 九州大学学位論文, 2000.

7) 吉田明徳, 村上啓介, 高比良智成：2 成分ストークス 波と没水構造物との非線形干渉解析, 海岸工学講演会 論文集，第41巻，pp. 736-740，1994.

8) 吉田明徳, 村上啓介, 山城賢: 多成分不規則波と没水 構造物との非線形干渉解析, 海岸工学講演会論文集, 第43巻, pp. 791-796, 1996. 